\title{
Párkapcsolati stabilitás és minôség egy országos kutatás tükrében
}

A család intézményének felgyorsult változásait láthatjuk az utóbbi néhány évtizedben, amely többek között megmutatkozik a házasságkötések számának csökkenésében, az élettársi kapcsolatban élők számának növekedésében, a családi életciklus átalakulásában, a párkapcsolatok stabilitásának csökkenésében. A termékenység csökkenése és az egyéni életút meghosszabbodása, mint két meghatározó demográfiai változás mellett a válások számának, pontosabban a teljes válási arányszámának $^{1}$ a növekedése jelentős hatással bír a család strukturális változására. Míg a válások száma hazánkban a 90-es évek közepétől stagnál, majd csökken, a teljes válási arányszám folyamatosan nő: 1990-ben a házasságok 31\%-a, 2000-ben 38\%-a, 2010-ben 46\%-a végződik válással (www.ksh.hu).

A családi stabilitás vizsgálatakor elengedhetetlen a család minőségi jellemzőinek felmérése is. Egyrészt a családi stabilitás fontos meghatározója a minőség, másrészt a rossz minőségú, de fennmaradó kapcsolatok hasznos adalékkal szolgálnak a családi múködés megértéséhez.

A jól funkcionáló családok támogató szerepe az élet minden területére kihat (pl: a gyermekek sikeres szocializációja, a devianciákkal és testi-lelki betegségekkel szembeni védőfaktor), ezzel szemben a rossz minőségú, instabil házasságokhoz inkább negatív következmények sorolhatók (Gödri 2001:10-11).

A családi instabilitást és minőséget érintő kutatásokban számos tényező merült fel, amely összefüggést mutat a válási hajlammal, illetve a kapcsolatok felbomlásával. Több tanulmány is felhívta a figyelmet a házasságkötéskor betöltött kor és a házassági instabilitás közötti kapcsolatra (Bumpass-Sweet 1972: 755-756.; Weed 1974: 373.; Lee 1977: 498.). A vizsgálatok szerint nagyobb a valószínúsége a fiatalon kötött házasságok felbomlásának. Booth és Edwards rámutattak arra, hogy nemcsak a korai, hanem a későn kötött házasságok is sérülékenyebbnek bizonyulnak (1985: 71.).

A kutatásokból konzisztensen látszik az is, hogy a szülők válása hatással van a gyermekeik későbbi párkapcsolati stabilitására (Bumpass-Martin-Sweet 1991: 28.; Amato 1996: 637.). Ez az összefüggés azonban az elvált szülők lányainál egyértelmú, a férfiaknál nincs szignifikáns kapcsolat (vagy nagyon gyenge) a két változó között (Feng és társai 1999: 459.). A téma vizsgálatához jó elméleti megközelítést ad Gery Becker gazdasági elmélete a házasságról és a házassági instabilitásról, mely többek között érinti a házimunka megosztását, jövedelmi viszonyokat a csa-

1 A teljes válási arányszám arra a kérdésre ad választ, hogy a házasságoknak meghatározott idôintervallumon belül hányad része végződik válással. 
ládon belül, a házasságkötési életkort, a házasfelek közötti eltéréseket (iskolai végzettség, életkor, vallás stb.), a házasság időtartamát, a nemi szerepekkel kapcsolatos attitúdöket (Becker 1977: 1156-1157.).

Jelen tanulmány célja egyrészt Becker hipotéziseinek ellenőrzése, másrészt a párkapcsolati stabilitás és minőség egyéb tényezőinek feltárása. A másodelemzés adatainak forrása: KSH Népességtudományi Kutatóintézet, „Életünk fordulópontjai" társadalmi-demográfiai alapfelvétel 3. adatfelvételi hullám. Becker hipotézisei házasságban élő́kre vonatkoznak, azonban azokat a párkapcsolatban élőket is vizsgáltam, akik nem kötöttek házasságot.

\section{A minta bemutatása}

A kutatás harmadik hullámának mintája 11.768 főből áll. A válaszadók fele családi állapotát tekintve házas, közel egyharmada egyedülálló, egytizede elvált és 5\%a özvegy. A kutatási kérdés szempontjából azonban elsősorban nem a hivatalos családi állapot a mérvadó, hanem a tényleges családi helyzet. Ezért a vizsgált célcsoport kritériumainak megfelelően a mintát 2 lépésben szúkítettem: 1. 20-65 év közöttiek (N=9284) 2. 20-65 év közötti párkapcsolatban élók (N=5930).

A szúkített mintában a nők aránya 55\%, átlagéletkor 44,27 év. A válaszadók 16\%-a 8 általános vagy az alatti iskolai végzettséggel rendelkezik, 30\% szakiskolát végzett, a válaszadók egyharmada érettségizett szakközépiskolában vagy gimnáziumban, a válaszadók $21 \%$-a rendelkezik felsőfokú végzettséggel. A mintába kerültek 65\%-a dolgozik, 9\%-uk nyugdíjas, ugyanennyien rendelkeznek valamilyen tartós egészségkárosodással, 6,3\%-uk gyermekgondozással kapcsolatos ellátásban részesül, a munkanélküliek aránya 5,2\%.

Az elemzésbe vont függő változók:

- a párkapcsolat instabilitása: „Az elmúlt egy évben felmerült-e a válás, a kapcsolat megszakításának gondolata?” A válaszlehetőségek között megjelenik kognitív és viselkedési elem is. Az alacsony elemszámok és a használt elemzési módszer miatt kétértékú változóvá alakítottam.

- a párkapcsolat minősége:

> párkapcsolattal való elégedettség

$>$ háztartási munkák megosztásával való elégedettség

$>$ gyermekneveléssel kapcsolatos munkák megosztásával való elégedettség > vita gyakorisága (különböző területeken)

\section{Eredmények}

\section{Becker hipotéziseinek ellenórzése}

Becker hipotéziseinek döntô része a párkapcsolatban élő felek különbségeire vonatkozik, ezért vizsgálatukhoz mindkét féltől származó (de legalábbis mindkét félre vo- 
natkozó) adatok szükségesek. Az elemzett kutatásban számos, a partnerre vonatkozó kérdés szerepel, azonban vannak olyan feltevések, melyek nem ellenőrizhetők.

Az elemzés során az Életünk fordulópontjai adatait összevetettem Huber és Spitze vizsgálatával (1980), amely szintén Becker hipotézisei alapján vizsgálta a házassági instabilitást.

1. A nók nagyobb valószínúséggel és többet gondolnak a válásra, mint a férfiak. Az elmúlt egy évben a válás gondolata a válaszadók 7\%-ánál merült fel, a nőknél valamennyivel nagyobb arányban (8,7\%), míg a férfiak 4,9\%-a gondolt a válásra - szignifikáns (Sig.: 0,000), de meglehetősen gyenge kapcsolatról van szó (Phi: 0,074).

Huber és Spitze eredményei is azt mutatják, hogy a feleségek gyakrabban gondolnak a válásra (nôk 30\%; férfiak 22\%²). A kölcsönösség tekintetében elmondható, hogy a válásra gondoló férfiak feleségeinek több mint a fele $(51 \%)$ esetében szintén felmerült a válás gondolata; a válásra gondoló feleségek férjeinek azonban csak 38\% jelezte ezt (Huber-Spitze 1980: 81-82.).

A kapcsolat megszakításának felmerülése jellemzóbb a nőkre, ez egybecseng azzal a ténnyel, hogy a válóperek többségét a női fél kezdeményezi (Gödri 2001: 4.).

\section{A feleség jövedelmének és a férj jövedelmének aránya hatással van mindkét fél válásról való gondolkodására.}

\section{1. táblázat - A családi jövedelmek eloszlása és a válás gondolatának felmerülése}

\begin{tabular}{|l|cc|}
\hline & $\begin{array}{c}\text { Felmerült-e a válás gondolata? } \\
\text { nók } \\
\text { férfiak } \\
(\mathbf{N = 2 1 8 2})\end{array}$ & $\begin{array}{c}\text { (N=1704) } \\
\text { Partnere többet keres }\end{array}$ \\
\hline Ugyanannyit keresnek & 7,1 & 5,9 \\
\hline Többet keres, mint a partnere & 10,1 & 5,3 \\
\hline Sig.: & 12,7 & 4,9 \\
\hline Cramer's V &, 006 &, 843 \\
\hline
\end{tabular}

A családon belüli jövedelmi viszonyokat vizsgálva láthatjuk, hogy a válaszadók jelentős része $(42,6 \%)$ hasonló mértékú jövedelemmel rendelkezik, mint partnere.

Elmondható továbbá, hogy míg a férfiak $12 \%$-a rendelkezik alacsonyabb jövedelemmel, mint partnere, a nők esetében ez 43\%. A válás gondolatának felmerülése a férfiaknál és a nőknél a jövedelmi viszonyokat tekintve ellentétes irányba mutat. A többet kereső férfiaknál a legalacsonyabb azoknak aránya, akikben felmerült

2 A két adat közötti különbség az eltérő operacionalizálás eredménye. Míg Huber és Spitze vizsgálatukban azt kérdezte, hogy felmerült-e valaha a válás gondolata, addig a hazai kutatásban az elmúlt egy évre kérdeztek rá. 
a válás gondolata, és a legmagasabb azoknál, akik kevesebbet keresnek, mint a partnerük. Ezzel szemben a nőknél kevesebbet keresôk kapcsolata látszik stabilabbnak, míg a partnerüknél többet keresők inkább gondolnak a válásra. A jövedelmi különbségek és a válás felmerülése közötti kapcsolat azonban csak a nők esetében szignifikáns. Úgy tûnik, hogy a férfiaknak kevésbé fontos a jövedelmi különbség, míg a párjuknál jobban keresố nőknél majdnem kétszeresére nőtt azoknak aránya, akiknél felmerült a válás gondolata.

Huber és Spitze vizsgálata szerint sem a felek abszolút jövedelmének, sem a jövedelmi különbségeknek nincs hatásuk a válás felmerülésére (Huber-Spitze 1980: 82.).

\section{A fiatalon házasodott személyeknél gyakrabban merül fel a válás gondolata, mert korlátozott idöt szántak a keresésre.}

A változószettben a házasodási életkorra irányuló kérdés nem szerepel, ezért a válaszadó születési éve és a partnerrel való együttélés kezdetének dátuma alapján számoltam. Azok a válaszadók, akik 20 éves koruk előtt, illetve akik több mint 30 évesen kötöttek házasságot vagy léptek élettársi kapcsolatba, gyakrabban gondolnak válásra, mint azok, akik kapcsolatukat 20 és 30 éves koruk között kezdték (20 év alatt: 8,4\%, 21-30 évesen: 6,2\%, 31 év felett: 8,1\%). A nemet kontrollváltozóként bevonva azonban azt látjuk, hogy a válás felmerülése és az együttélés kezdetekor betöltött életkor változók kapcsolata látszólagos - a nem mindkét változóra hatással van.

Huber és Spitze adatai alapján a változók közötti kapcsolat nem tûnt el, azonban specifikálódott: a nők esetében a fiatalon kötött házasság a válási hajlam növekedésével járt, a férfiaknál nem jelent meg az eredeti összefüggés (Huber-Spitze 1980: 83.).

4. A fiatal gyermekkel rendelkezó családoknál csökken a valószínúsége a válás felmerülésének mindkét félnél, de jobban a feleségeknél, mivel rendszerint-válás esetén - nekik kell gondoskodniuk a gyermekekról a munkavállalás mellett.

A kutatásból származó adatok nem támasztják alá a hipotézist. Mind a nôknél, mind a férfiaknál valamennyivel magasabb a válás felmerülése azokban a kapcsolatokban, ahol 6 év alatti gyermek van, tehát a feltevésünkkel éppen ellentétes - ez a kapcsolat azonban egyik nemnél sem szignifikáns.

Huber-Spitze tanulmányukban arra mutattak rá, hogy a 6 év alatti gyermek a férjeknél csökkenti a válás felmerülésének valószínúségét, míg a 7-11 éves korú gyermekes nőknél növekszik a válás felmerülésének valószínúsége (Huber-Spitze 1980: 83-84.).

Úgy tûnik, a gyermek családösszetartó szerepe már nem olyan hangsúlyos, mint néhány évtizede. Mivel a 2008-as adatok alapján a kapcsolat egyik nem esetében sem szignifikáns, a párkapcsolat stabilitását nem befolyásolja döntôen, hogy van-e gyermekük (Sig: Nők: ,269; Férfiak: ,475) illetve hogy milyen korú a gyermek (Sig: Nők: ,538; Férfiak: ,224). 
5. A párok jellemzói (iskolai végzettség, kor, vallás) közötti nagyobb eltérések emelik a válás gondolatának felmerülését mindkét fél esetén.

A kor és iskolai végzettség tekintetében vannak adataink mindkét félre vonatkozóan. A felek közötti abszolút korkülönbség növekedésével nő azoknak az aránya, akiknél felmerült a válás gondolata, azonban egyik nemnél sem szignifikáns a kapcsolat.

2. táblázat - Korkülönbség és a válás gondolatának felmerülése

\begin{tabular}{|c|c|c|c|}
\hline & \multicolumn{3}{|c|}{ Felmerült-e a válás gondolata? (\%) } \\
\hline & $\begin{array}{c}\text { nók } \\
\text { (N=3267) }\end{array}$ & $\begin{array}{c}\text { férfiak } \\
(\mathrm{N}=2645)\end{array}$ & Össz. \\
\hline A partner fiatalabb & 10,2 & 4,8 & 5,6 \\
\hline Hasonló korúak & 8,3 & 4,6 & 6,7 \\
\hline A partner idősebb & 9,0 & 7,0 & 8,8 \\
\hline Sig.: &, 612 &, 371 &, 003 \\
\hline Cramer's V &, 017 &, 027 & 0,44 \\
\hline
\end{tabular}

A relatív korkülönbség szignifikáns kapcsolatot mutat a válás gondolatával, azonban a nem bevonásával láthatjuk, hogy a parciális kapcsolatok már nem szignifikánsak (fiatalabb partnerről többnyire a férfiak számoltak be, míg idősebbról a nôk).

Az iskolai végzettségek különbségeit vizsgálva láthatjuk, hogy a válás felmerülésére egyik nemnél sincs hatása a különbségeknek.

Huber és Spitze vizsgálatában az iskolai végzettségbeli különbségek nem voltak hatással a válás felmerülésére. A korkülönbség csak a férfiaknál volt szignifikáns: azon férfiaknál, akik idősebbek a feleségüknél, alacsonyabb a válás felmerülésének valószínúsége. A legnagyobb hatása a vallásbeli különbségeknek volt - a katolikus vagy nem vallásos feleségek protestáns férjeinél merül fel leggyakrabban a válás gondolata (Huber-Spitze 1980: 84.).

6. A dolgozó feleségekben, akik úgy érzik, hogy egyenlöen kellene megosztani a házimunkát a férjükkel, de mégis a nagyobb részét ók csinálják, gyakrabban merül fel a válás gondolata, mint más feleségekben.

A munkavállalás önmagában nincs szignifikáns hatással a válás gondolatának felmerülésére, bár a dolgozó nők körében gyakoribb. A házimunka egyenlőtlensége azonban összefügg a stabilitással - azok a nôk, akik az otthoni munkák döntő részét végzik, nagyobb arányban gondolnak a válásra.

\section{A párkapcsolati stabilitás és minóség egyéb tényezốinek feltárása}

Az Életünk fordulópontjai adatfelvételben szerepelt néhány fontos változó, melyet Becker hipotézisei nem érintenek, azonban hatással lehetnek a kapcsolati stabilitásra.

Számos kutatásban vizsgálták a családforma (házasság vagy élettársi kapcsolat) és a stabilitás-minőség összefüggéseit. Az Életünk fordulópontjai kutatás adatai 
egybecsengenek a korábbi kutatások eredményeivel: a házasságban élők kapcsolatai stabilabbnak bizonyultak, mint az élettársi kapcsolatban élő pároké (Pongráczné 2009: 16., Kamp Dush és társai 2003: 544., Amato és társai 2003: 4.). Az élettársi kapcsolatban élők 12,6\%-ánál, míg a házasságban élők 5,7\%-ánál merült fel a válás gondolata (Sig.: ,000; Phi: ,104). Amint korábban említettem, a stabilitásra azonban olyan külső tényezók is hatással vannak, mint a kapcsolat elérhetô alternatívái és a lehetséges gátak. Feltételezhetjük, hogy a házassági kapcsolat megszakításánál ezek a gátak erôteljesebbek. A családformát a párkapcsolattal való elégedettséggel összevetve láthatjuk, hogy a házasságban élők elégedettebbek (Sig.: ,000; Cramer's V: ,064) - tehát nem csak a külső tényezőknek tulajdonítható a stabilitásban tapasztalható különbség.

A kutatás során rákérdeztek arra, hogy a felek milyen gyakran vitatkoznak egyes témák miatt. A leggyakoribb vitaokok között találjuk az anyagi ügyeket, a gyermeknevelési kérdéseket, a házimunka megosztását, valamint a szabadidő eltöltését. Ha a különböző vitaokokat nézzük, mindegyik szignifikáns kapcsolatot mutat a válás gondolatának felmerülésével. Általában a kapcsolat a nők esetében erősebb, néhány vitaok (féltékenység, közös célok, gyermekvállalás, gyermeknevelés) esetén megközelítőleg ugyanolyan erôsségú. A két fél között azoknál a vitaokoknál volt legnagyobb különbség (legalábbis a kapcsolat erősségében), amelyek modellbe építve is szignifikánsak maradtak: anyagi ügyek (Sig.: ,000 Cramer's V: ,302; ffi: ,213; nő: ,357) , házimunka megosztása (Sig.: ,000 Cramer’s V: ,211; ffi: ,155; nő: ,243), alkoholfogyasztás (Sig.: ,000 Cramer's V: ,305; ffi: ,200; nő: ,352). Ez felveti azt a kérdést, hogy a kapcsolat instabilitását az egyes kérdések körüli vita gyakorisága kevésbé befolyásolja, mint az, hogy a felek ,vita-definiálása” különböző.

Több kutató és konfliktuskezeléssel foglalkozó szakember felhívta arra is a figyelmet, hogy nem annyira a viták gyakorisága, mint a konfliktusok kezelésének módja hat a kapcsolat minőségére és stabilitására (Heavey és társai 1993: 21., Gottman 1993: 8., Lovas-Herczog 1999: 45.). Az elemzett adatbázisban a konfliktusok kezelésére vonatkozóan egy kérdés szerepelt: „Amikor Önnek komolyabb nézeteltérése támad párjával, milyen gyakran történik a következő?"

Az elkerülő magatartást választása (,Megtartja magának a véleményét, hogy elkerüljék a nagyobb vitát.”) szignifikáns kapcsolatot mutat a válás gondolatának felmerülésével.

\section{1. ábra - A válás felmerülésének aránya a véleményüket megtartóknál}

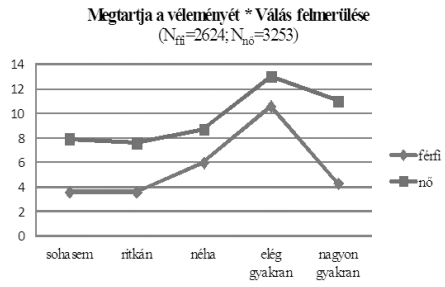


Azoknál a legalacsonyabb a válás felmerülésének valószínúsége, akik nyíltan kifejezik véleményüket, elsősorban nem a vita elkerülésére törekszenek. Mindkét nemnél a legmagasabb a válás gondolatának felmerülése abban az esetben, ha elég gyakran választják ezt a kezelési módot, érdekes módon azonban a nagyon gyakran választóknál kisebb a válás felmerülésének valószínúsége (Sig.: ,000 Cramer's V: ,069; ffi: ,098; nő: ,057). Logikus magyarázat lehetne erre, hogy ebben az esetben a stabilitás és a minőség dimenzió külön mozog, azonban a kapcsolattal való elégedettség esetében is hasonló mintázatot láthatunk.

\section{2. ábra - A válás felmerülésének aránya a problémákat nyugodtan megbeszélóknél}

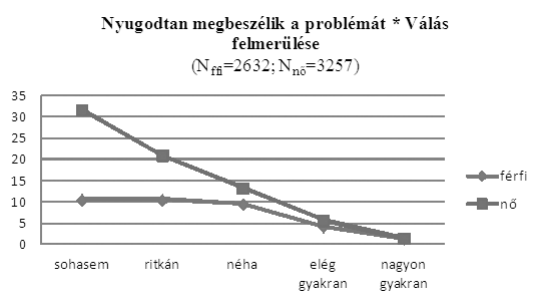

A felmerülő problémák nyílt és nyugodt megbeszélése nagymértékben csökkenti a válás gondolatának felmerülését mindkét nemnél. Míg a problémák nyugodt megbeszélése pozitívan hat a felekre, ennek elmaradása különbözó intenzitással befolyásolja a válás felmerülésének valószínúségét a nôknél és a férfiaknál: a férfiaknál kb. tízszeresére nő, ezzel szemben a nőknél több mint hússzorosára emelkedik a váláson gondolkodók aránya (Sig.: ,000 Cramer’s V: ,242; ffi: ,163; nő: ,291).

\section{3. ábra - A válás felmerülésének aránya az egymással veszekedó, kiabáló pároknál}

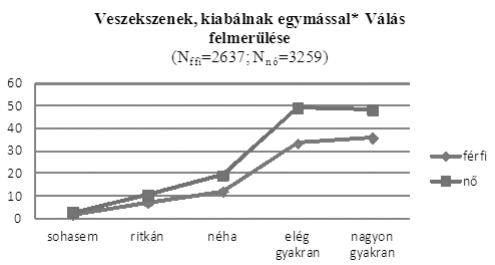

Azoknál a pároknál, ahol a problémára való jellemző reakció a veszekedés és az egymással való kiabálás, nagymértékben csökken a kapcsolati stabilitás: a párjukkal elég gyakran veszekedő nők fele, a férfiak egyharmada gondolt válásra az elmúlt egy év során. Az ábrán láthatjuk, hogy mindkét nem esetén már az ,elég gyakran” kategóriánál eléri a maximumot a válás gondolatának felmerülése, azaz elmondható, hogy az egymással való gyakori veszekedés, kiabálás mindkét nemnél 
egyértelmúen növeli a válás valószínűségét (Sig.: ,000 Cramer’s V: ,327; ffi: ,278; nő: ,352).

3. táblázat - A válás felmerülésének aránya tettlegesség esetén

\begin{tabular}{|l|cc|}
\hline & \multicolumn{2}{|c|}{$\begin{array}{c}\text { Tettlegességig fajul a dolog* } \\
\text { Válás felmerülése }(\%) \\
(\text { Nffi=2636; Nnő=3259) }\end{array}$} \\
\hline & Sohasem & Előfordul \\
\hline Férfi & 4,6 & 34,5 \\
\hline Nő & 7,8 & 65,2 \\
\hline
\end{tabular}

A problémára adott negyedik reakciótípus a tettlegesség előfordulása volt. A családon belüli erőszak kérdésköre rendkívül kényesnek és nehezen felmérhetônek számít, ami nagy körültekintést igényel mind az adatfelvétel, mind az elemzés során (Tóth 2003: 105.).

A gyakoriságra kérdező változót az egyes cellákra eső alacsony elemszám miatt kétértékúvé kódoltam. Azokban a kapcsolatokban, ahol egy-egy probléma „,kezelése" a tettlegességig fajul, a nók kétharmada, a férfiaknak pedig egyharmada gondol válásra (Sig.: ,000 Phi: ,209; ffi: ,160; nő: ,241).

4. táblázat: A válás felmerülése - logisztikus regresszió

\begin{tabular}{|lccc}
\multicolumn{4}{c}{ A logisztikus regressziós elemzés eredménye } \\
& \multicolumn{3}{c}{ Felmerült-e az elmúlt egy } \\
& \multicolumn{3}{c}{ évben a válás gondolata? } \\
& B & Sig & Esély-hányados \\
&, 710 & $\mathbf{, 0 0 3}$ & 2,033 \\
\hline Nem &, 596 & $\mathbf{, 0 0 0}$ & 1,815 \\
\hline Vita - anyagi ügyek &, 510 & $\mathbf{, 0 0 0}$ & 1,665 \\
\hline Vita - közös célok &, 502 & $\mathbf{, 0 0 0}$ & 1,652 \\
\hline Vita - alkohol &, 355 & $\mathbf{, 0 1 1}$ & 1,426 \\
\hline Vita - féltékenység &, 235 & $\mathbf{, 0 0 2}$ & 1,265 \\
\hline Konf - hallgat &, 312 & $\mathbf{, 0 0 5}$ & 1,367 \\
\hline Konf veszekszik & 1,218 & $\mathbf{, 0 1 0}$ & 3,382 \\
\hline Konf - tettlegesség &, 463 & $\mathbf{, 0 0 0}$ & 1,590 \\
\hline Konz-lib faktor & & & \\
\hline Cox\&Snell R ${ }^{2}:, 168$ & & & \\
\hline Nagelkerke R ${ }^{2}:, 398$ & &
\end{tabular}


A kapcsolati instabilitást befolyásoló változókat bináris logisztikus regresszió módszerével modellbe építettem, ahol a függố változó a válás gondolatának felmerülése volt. A modellbe léptetés előtt néhány változó ${ }^{3}$ kivételével szignifikáns kapcsolatokat láthatunk. A modellben a táblázatban szereplő változók maradtak szignifikánsak.

A feltárt kapcsolatok specifikálása végett a regressziós eljárást elvégeztem külön a nôkre és a férfiakra is. A férfi almintán a következő változók maradtak a modellbe építve is szignifikánsak: szülőkkel való kapcsolat miatti vita, közös célok miatti vita, konfliktuskezelés - megtartja a véleményét; konfliktuskezelés - veszekszik.

A női almintán szignifikáns maradt: anyagi ügyek miatti vita, közös célok miatti vita, alkohol miatti vita, féltékenység miatti vita, konfliktuskezelés - megtartja a véleményét, konfliktuskezelés - tettlegesség, konzlib faktor (melyet a házassággal kapcsolatos konzervatív, liberális attitúdöket jelző itemcsoport faktorelemzésével képeztem).

Ezek alapján elmondható, hogy a Becker által vizsgált változók nagy része már a modellbe lépés előtt sem volt szignifikáns, a modellbe építve pedig a demográfiai és társadalmi státuszra vonatkozó változók közül csak a nem maradt szignifikáns. A többi szignifikáns változó a párkapcsolat minőségéhez kapcsolható - viták gyakorisága, illetve azok kezelése, valamint a családdal kapcsolatos attitűdök. A férfiaknál jóval kevesebb és részben eltérô tényező maradt szignifikáns, mint a nőknél.

\section{Összegzés}

A párkapcsolati stabilitás vizsgálata során elmondható, hogy a nők gyakrabban gondolnak a válásra, és ez az összefüggés több esetben az egyéb változók válási hajlammal való (látszólagos) kapcsolatát magyarázza, olykor specifikálja. A nemen kívül nem találtam olyan demográfiai, illetve társadalmi státuszhoz kapcsolódó változót, amely szignifikáns kapcsolatot mutatott volna a válás felmerülésével. A kapcsolattal való elégedettségen kívül néhány olyan változó hatása mutatható ki a stabilitásra, amelyek a kapcsolat minőségének indikátorai lehetnek - így a vita gyakorisága, a konfliktuskezelés. A problémák nyugodt megbeszélése jelentősen hozzájárul a kapcsolatok stabilitásához, ennek hiánya azonban elsősorban a nőket befolyásolja. A vitaokokat tekintve is azt láthatjuk, hogy a nôk esetében több olyan vitatéma van, amely - gyakori nézeteltérés esetén - a válás gondolatának felmerülése felé mutat.

A kérdés vizsgálata további kutatást indokol, melyben szükséges egyrészt a változók (stabilitás, konfliktuskezelés) árnyaltabb mérése, másrészt a családi minőség vizsgálatához szinte elengedhetetlen mindkét féltől származó adatok elemzése.

3 A következő változók esetén nincs szignifikáns kapcsolat a válás felmerülésével: dolgozik-e, jövedelemkülönbség, van-e gyermek, legfiatalabb gyermek életkora, iskolai végzettség különbsége. A táblázatban terjedelmi korlátok miatt csak a szignifikáns változók kerültek feltüntetésre. 


\section{Hivatkozott irodalom}

Амато, P. R. (1996): Explaining the Intergenerational Transmission of Divorce. Journal of Marriage and Family 58 (3), 628-640.

Amato, P. R.-Johnson, D. R.-Booth, A.-Rogers, S. J. (2003): Continuity and change in marital quality between 1980 and 2000. Journal of Marriage and Family 65 (1), 1-22.

Becker, G.-Landes, E. M.-Michael, R. (1977): An Economic Analysis of Marital Instability. Journal of Political Economy 85 (6), 1141-1187.

Booth A.-Edwards, J. N. (1985): Age at Marriage and Marital Instability. Journal of Marriage and Family 47 (1), 67-75.

Bumpass, L.-SweEt, J. (1972): Differentials in Marital Instability, 1970. American Sociological Review 37 (6), 754-766.

Bumpass, L.-Martin, T. C.-SweEt, J. (1991): The Impact of Family Backround and Early Marital Factors on Marital Disruption. Journal of Family Issues $12(1), 22-42$.

FenG, D.-Giarrusso, R.-Bengtson, V. L-Frye, N. (1999): Intergenerational Transmission of Marital Quality and Marital Instability. Journal of Marriage and Family 61, 451-463.

GotTman, J. M. (1993): The Roles of Conflict Engagement, Escalation, and Avoidance in Marital Interaction: A Longitudinal View of Five Types of Couples, Journal of Consulting and Clinical Psychology 61 (1), 6-15.

GöDRI IRÉN (2001): A házassági kapcsolatok minösége és stabilitása. Budapest, KSH NKI.

Heavey, C. L.-Layne, C.-Christensen, A. (1993): Gender and Conflict Structure in Marital Interaction: A Replication and Extansion. Journal of Consulting and Clinical Psychology 61 (1), 16-27.

Huber, J.,-Spitze, G. (1980): Considering Divorce: An Expansion of Becker's Theory of Marital Instability. American Journal of Sociology 86 (1), 75-89.

Kamp Dush, C. M.-Cohan, C. L.-Amato, P. R. (2003): The Relationship Between Cohabitation and Marital Quality and Stability: Change across Cohorts? Journal of Marriage and Family 65 (3), 539-549.

LeE, G. R. (1977): Age at Marriage and Marital Satisfaction: A Multivariate Analysis with Implications for Marital Instability. Journal of Marriage and the Family 39 (3), 493-504.

LOVAs ZsuzSA-HERCZOG MÁRIA (1999): Mediáció, avagy a fájdalommentes konfliktuskezelés. Budapest, Múzsák.

PongRácZ TiBORNÉ (2009): A párkapcsolatok jellegzetességei. In Monostori-ŐriMolnár-Spéder (szerk.): Demográfiai portré 2009. Budapest, KSH NKI, 9-18.

TóтH OlgA (2003): A családon belüli, partner elleni erőszak. Új folyam (27), 101-115. WeED, J. A. (1974): Age at Marriage as a Factor in State Divorce Rate Differentials. Demography 11 (3), 361-375. 